\title{
Front Matter: Volume 9841
}

, "Front Matter: Volume 9841," Proc. SPIE 9841, Geospatial Informatics, Fusion, and Motion Video Analytics VI, 984101 (12 August 2016); doi: $10.1117 / 12.2245789$

SPIE. Event: SPIE Defense + Security, 2016, Baltimore, MD, United States 


\title{
PROCEEDINGS OF SPIE
}

\section{Geospatial Informatics, Fusion, and Motion Video Analytics VI}

\author{
Matthew F. Pellechia \\ Kannappan Palaniappan \\ Peter J. Doucette \\ Shiloh L. Dockstader \\ Gunasekaran Seetharaman \\ Editors
}

19-21 April 2016

Baltimore, Maryland, United States

Sponsored and Published by

SPIE 
The papers in this volume were part of the technical conference cited on the cover and title page. Papers were selected and subject to review by the editors and conference program committee. Some conference presentations may not be available for publication. Additional papers and presentation recordings may be available online in the SPIE Digital Library at SPIEDigitallibrary.org.

The papers reflect the work and thoughts of the authors and are published herein as submitted. The publisher is not responsible for the validity of the information or for any outcomes resulting from reliance thereon.

Please use the following format to cite material from these proceedings:

Author(s), "Title of Paper," in Geospatial Informatics, Fusion, and Motion Video Analytics VI, edited by Matthew F. Pellechia, Kannappan Palaniappan, Peter J. Doucette, Shiloh L. Dockstader, Gunasekaran Seetharaman, Proceedings of SPIE Vol. 9841 (SPIE, Bellingham, WA, 2016) Six-digit Article CID Number.

ISSN: 0277-786X

ISSN: 1996-756X (electronic)

ISBN: 9781510600829

Published by

SPIE

P.O. Box 10, Bellingham, Washington 98227-0010 USA

Telephone +1 3606763290 (Pacific Time) · Fax +1 3606471445

SPIE.org

Copyright @ 2016 , Society of Photo-Optical Instrumentation Engineers.

Copying of material in this book for internal or personal use, or for the internal or personal use of specific clients, beyond the fair use provisions granted by the U.S. Copyright Law is authorized by SPIE subject to payment of copying fees. The Transactional Reporting Service base fee for this volume is $\$ 18.00$ per article (or portion thereof), which should be paid directly to the Copyright Clearance Center (CCC), 222 Rosewood Drive, Danvers, MA 01923 . Payment may also be made electronically through CCC Online at copyright.com. Other copying for republication, resale, advertising or promotion, or any form of systematic or multiple reproduction of any material in this book is prohibited except with permission in writing from the publisher. The CCC fee code is $0277-786 \mathrm{X} / 16 / \$ 18.00$.

Printed in the United States of America.

Publication of record for individual papers is online in the SPIE Digital Library.

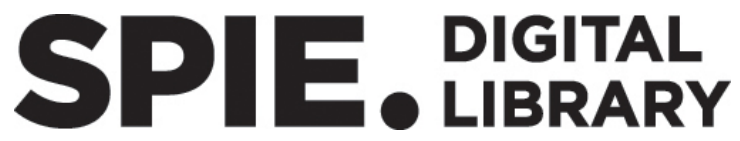

SPIEDigitalLibrary.org

Paper Numbering: Proceedings of SPIE follow an e-First publication model, with papers published first online and then in print. Papers are published as they are submitted and meet publication criteria. A unique citation identifier (CID) number is assigned to each article at the time of the first publication. Utilization of CIDs allows articles to be fully citable as soon as they are published online, and connects the same identifier to all online, print, and electronic versions of the publication. SPIE uses a six-digit CID article numbering system in which:

- The first four digits correspond to the SPIE volume number.

- The last two digits indicate publication order within the volume using a Base 36 numbering

system employing both numerals and letters. These two-number sets start with 00, 01, 02, 03, 04, $05,06,07,08,09,0 A, 0 B \ldots$. OZ, followed by 10-1Z, 20-2Z, etc.

The CID Number appears on each page of the manuscript. The complete citation is used on the first page, and an abbreviated version on subsequent pages. 


\title{
Contents
}

\author{
$\checkmark$ Authors \\ vii Conference Committee
}

GEOINFORMATIC EMERGING ARCHITECTURES AND TECHNOLOGIES

984105 Looking at Earth observation impacts with fresh eyes: a Landsat example [9841-5]

984107 Gender classification of running subjects using full-body kinematics [9841-7]

984109 Smart phone orientation estimation comparisons using three axis gimbal [9841-9]

GEOINFORMATICS PROCESSING AND ANALYTICS I

9841 OB Automated scene generated background context for near-nadir look angles [9841-11]

GEOINFORMATICS PROCESSING AND ANALYTICS II

9841 OE Optimal multi-focus contourlet-based image fusion algorithm selection [9841-15]

9841 OF Bandelet-based image fusion: a comparative study for multi-focus, multi-modal images [9841-16]

\section{GEOINFORMATICS PROCESSING AND ANALYTICS III}

9841 ol Multi-focus and multi-modal fusion: a study of multi-resolution transforms [9841-19]

9841 0J A comparative study of multi-focus image fusion validation metrics [9841-20]

$98410 \mathrm{~K}$ Interacting with target tracking algorithms in a gaze-enhanced motion video analysis system [9841-21]

9841 OM Evaluation of H.264 and H.265 full motion video encoding for small UAS platforms [9841-23] 
Proc. of SPIE Vol. $9841984101-4$

Downloaded From: https://www.spiedigitallibrary.org/conference-proceedings-of-spie on 26 Apr 2023 Terms of Use: https://www.spiedigitallibrary.org/terms-of-use 


\section{Authors}

Numbers in the index correspond to the last two digits of the six-digit citation identifier (CID) article numbering system used in Proceedings of SPIE. The first four digits reflect the volume number. Base 36 numbering is employed for the last two digits and indicates the order of articles within the volume. Numbers start with 00, 01, 02, 03, 04, 05, 06, 07, 08, 09, 0A, OB...0Z, followed by 10-1Z, 20-2Z, etc.

Alford, Mark, OE, OF, OI, OJ

Babcock, Michael, 05

Beyerer, Jürgen, OK

Blasch, Erik, OE, OF, OI, OJ

Bubalo, Adnan, Ol, OJ

Dale, Erin, 05

Doucette, Peter, 05

Ezekiel, Soundararajan, OE, OF, OI, OJ

Fields, MaryAnne, 09

Flora, Jeffrey B., 07

Gaquin, Kevin G., 09

Giansiracusa, Michael, OE, OF, Ol, OJ

Heinze, Norbert, OK

Hild, Jutta, OK

Hill, Kerry, OM

Hoffman, Marc, OM

Iftekharuddin, Khan M., 07

Krüger, Wolfgang, OK

Lutz, Adam, OE, OF, Ol, OJ

Manno, Michael, OJ

McGuinness, Christopher D., OM

Messer, Neal, OE, OF, OJ

Peinsipp-Byma, Elisabeth, OK

Quirk, Bruce, 05

Snyder, Greg, 05

Stanfill, S. Robert, OB

Stensaas, Greg, 05

Taylor, Clark, OM

Thomas, Millicent, 0 I

Tucker, Jonathan D., OB

Vadnais, Carolyn, 05

Walker, David, OM

Williams, Christina M., 07

Wu, Zhuoting, 05 
Proc. of SPIE Vol. $9841984101-6$

Downloaded From: https://www.spiedigitallibrary.org/conference-proceedings-of-spie on 26 Apr 2023 Terms of Use: https://www.spiedigitallibrary.org/terms-of-use 


\section{Conference Committee}

Symposium Chair

David Logan, BAE Systems (United States)

Symposium Co-chair

Donald A. Reago Jr., U.S. Army Night Vision \& Electronic Sensors Directorate (United States)

Conference Chairs

Matthew F. Pellechia, Harris Corporation (United States)

Kannappan Palaniappan, University of Missouri-Columbia (United States)

Peter J. Doucette, U.S. Geological Survey (United States)

Shiloh L. Dockstader, Harris Corporation (United States)

Gunasekaran Seetharaman, U.S. Naval Research Laboratory (United States)

Conference Program Committee

Alex Aved, Air Force Research Laboratory (United States)

John A. Berger, Toyon Research Corporation (United States)

Erik P. Blasch, Air Force Research Laboratory (United States)

Bernard V. Brower, Harris Corporation (United States)

Subhasis Chaudhuri, Indian Institute of Technology Bombay (India)

Larry S. Davis, University of Maryland, College Park (United States)

Mark A. Duchaineau, Google (United States)

Adel Hafiane, Ecole Nationale Supérieure d'Ingénieurs (France)

Gregory F. S. Hewitt, Applied Research Associates, Inc. (United States)

Simon J. Julier, University College London (United Kingdom)

Haibin Ling, Temple University (United States)

Peter Paul, Xerox Corporation (United States)

Robert B. Pless, Washington University in St. Louis (United States)

V. B. Surya Prasath, University of Missouri-Columbia (United States)

Kari A. Pulli, NVIDIA Corporation (United States)

Ambasamudram Rajagopalan, Indian Institute of Technology Madras (India)

Raghuveer M. Rao, U.S. Army Research Laboratory (United States)

John A. Richards, Sandia National Laboratories (United States)

Sartaj Sahni, University of Florida (United States)

Carl Salvaggio, Rochester Institute of Technology (United States)

Stephen Se, MacDonald, Dettwiler and Associates Ltd. (Canada) 
Stefano Soatto, University of California, Los Angeles (United States)

Suresh Subramanian, Lockheed Martin Missiles and Fire Control

(United States)

Bruce Swett, EOIR Technologies (United States)

George R. Thoma, National Library of Medicine (United States)

Karmon M. Vongsy, Air Force Research Laboratory (United States)

Kevin C. Yager, Harris Corporation (United States)

Darrell L. Young, Raytheon Intelligence \& Information Systems

(United States)

\section{Session Chairs}

1 Geoinformatics and New Applications

Kannappan Palaniappan, University of Missouri-Columbia (United States)

2 Geoinformatic Emerging Architectures and Technologies

Peter J. Doucette, U.S. Geological Survey (United States)

3 Geoinformatics Processing and Analytics I

Peter J. Doucette, U.S. Geological Survey (United States)

4 Geoinformatics Processing and Analytics II

Kannappan Palaniappan, University of Missouri-Columbia (United States)

5 Geoinformatics Processing and Analytics III

Peter J. Doucette, U.S. Geological Survey (United States) 